\title{
FISH OIL SUPPLEMENTATION AND SELENIUM-VITAMIN E INJECTION OF EGYPTIAN EWES AND THEIR FINNISH LANDRACE CROSSBRED DURING LATE PREGNANCY: 2. LAMBS RESPONSE
}

\author{
HAMADA D.H. MAHBOUB*; SAMEH G.A. RAMADAN*; RAGAB A. DARWISH**; \\ MOHAMED A. HELAL ${ }^{*}$; KHALID M. GAFAAR ${ }^{* * *}$ and T.A.M. ASHMAWY ${ }^{* * * *}$ \\ * Department of Husbandry and Animal Wealth Development, Faculty of Veterinary Medicine Sadat Branch, Menoufia \\ University. Egypt. \\ Email address: hamada11eg@yahoo.co.uk \\ ${ }^{* *}$ Department of Animal Husbandry, Faculty of Veterinary Medicine, Mansoura University, Mansoura, Egypt. \\ *** Department of Nutrition and Nutrional Deficiency Diseases, Faculty of Veterinary Medicine Sadat Branch, Menoufia \\ University. Egypt. \\ ${ }^{* * * *}$ Animal Production Research Institute, Ministry of Agriculture, Egypt.
}

\section{ABSTRACT}

Received at: 30/5/2013

Accepted: 19/6/2013
This work was designed to study the effects of fish oil supplementation and selenium-vitamin E (Se- vit. E) injection of Egyptian ewes and their Finnish Landrace Crossbred during the late stage of pregnancy on lambs response. Neonatal behaviors and growth performance of lambs including birth weight and average daily gain were recorded, while immune status of lambs was determined. Fifty-one pregnant ewes [native breeds (Ossimi and Rahmani, $\mathrm{n}=30$ ) and their crosses with exotic Finnish Landrace breed $(n=21)]$ were selected and allocated to 3 experimental groups ( $\mathrm{n}=17$ animals per group). The first group was fed with fish oil supplemented diet for 6 weeks prior to lambing (40 gm Sardine oil (ewe/day); while the second group was injected by 2 successive doses of Se- vit. E solution ( $5 \mathrm{ml}$ of $2 \mathrm{mg}$ sodium selinate and $100 \mathrm{mg}$ vitamin E) at 20 and 10 days before lambing. The third group was kept as a control. Lamb birth weight, neonatal behaviors, body temperature over the first $3 \mathrm{~d}$ of life, average daily weight gain and mortality rates of lambs from birth until weaning were recorded. Blood samples were collected from each lamb, first sample was collected presuckling and the second one was at $24 \mathrm{~h}$ after birth for determination of phagocytic activity, white blood cell counts and serum total protein, including albumin and globulin. Lambs born to ewes of control group weighed less at birth and have an increased latencies to stand, reach the udder and suck successfully, and with a lower pre-suckling body temperature compared with those born to ewes supplemented with fish oil or others injected by selenium-vitamin E. These differences were more particularly observed in lambs born to native ewes than those born to crossbred ewes. Hematological analysis showed significantly higher white blood cell counts and phagocytic activity in lambs born to supplemented ewes than those born to control ones. No significant differences were demonstrated in pre-suckling concentrations of total serum protein, albumin and globulin between lambs born to treated ewes and those born to untreated ones. However, at $24 \mathrm{~h}$ after birth, lambs born to supplemented ewes exhibited significantly higher concentrations of total protein and globulin than those born to control ewes. Moreover, lambs from supplemented ewes had significantly higher body weight gain with a minimal mortality rates from birth until weaning than those born to untreated ewes, specifically in ewes injected with selenium and vitamin E. We conclude that supplementing pregnant ewes with fish oil or selenium-vitamin $\mathrm{E}$ increases lamb birth weight, decreases the latency to stand and suckle and improves pre-suckling body temperature and immunocompetence of neonatal lambs with better lamb performance and survival. 


\section{INTRODUCTION}

The newborn lamb has little active immunity against diseases and so maternal immunity plays an essential role in the defense mechanism of lambs, until its own immune system is primed and produces a protective level of immunity (Brambell 1970; Mellor and Murray 1985, 1986). Failure of passive transfer of immunoglobulins to neonatal lambs has a major effect on neonatal mortality, and losses due to infectious causes are positively associated with low concentrations of serum antibodies (McGuire et al., 1983). For that reason, morbidity and mortality rates were highly recorded in colostrum-deprived lambs $(67-80 \%)$ than colostrum fed lambs $(13-20 \%)$ (Hodgson et al., 1992). As well, starvation, hypothermia, and scours were reported for most of lamb losses. It has been estimated that $45 \%$ of all lambs that die during the first few days of life can be contributed to inadequate colostrum intake (McGuire et al., 1983). Lamb deaths can be contributed to ewe's colostrum being of poor quantity or quality; inflamed udders; dysfunctional teats; multiple births; poor maternal care and neonatal lamb behaviour (Everett-Hincks et al., 2005b and Darwish et al., 2010); orphan or weak lambs; low birth weight and diseases (Christley et al., 2003). Formerly, it was supposed that only the ewe that played a role in the early establishment of the bonding process (Gubernick, 1981) but lamb behavior is also essential for forming the ewe-lamb bond (Nowak and Lindsay, 1990). Consequently, good ewe management before and during lambing and attention to early care of lambs which ensure reduce the time taken by lamb to stand and suckle and improve the immunity status will enhance the survival of newborn lambs.

Nutrition needs increases significantly in the last 4-6 weeks of pregnancy. It is important to support rapid fetal growth (70\% of growth occurs in last 6 weeks) and udder development for colostrum and milk production (Bell 1995; Dawson et al., 1999 and Mutassim, 2007). Moreover, selenium is an essential element in the diet of animals and has a variety of roles: such as an anti-oxidant that works in conjunction with vitamin $\mathrm{E}$ to prevent and repair cell damage in the body; it is implicated in immune function and is necessary for a number of metabolic processes, growth, and fertility (Sheppard et al., 1984). Selenium status in grazing crops is dependent on incorporation from soil, which in turn obtains most of its selenium from surrounding rocks. Selenium levels that occur in the Egyptian soil are considered low because the mean values of selenium in the soil as well as plants were 0.045 and 0.027 $\mathrm{mg} / \mathrm{kg}$ respectively (El-Raies, 2001). Beside that, selenium deficiency can interfere with the transport of vitamin E. On the other hand, crops, cereal grains and dry hays tend to be poor sources of vitamin $E$ and prolonged storage of feedstuffs results in a degradation of Vitamin E content. As well as vitamin $\mathrm{E}$ is intimately associated with selenium; both play the role of an antioxidant, and both have the ability to offset some deficiencies of the other (Hatfield et al., 2000). The most commonly recognized condition of vitamin E/selenium deficiency is the stiff lamb disease that may be present at birth and affected lambs may die from starvation and they are more susceptible to scours and acute pneumonia (Suttle et al., 1991).

There is much interest in the potential health benefits of the long chain polyunsaturated fatty acids (PUFA), which are found in abundance in fish oil. The long chain polyunsaturated fatty acids (PUFA), in particular arachidonic acid (AA, 20:4n-6) and docosahexaenoic acid (DHA, 22:6n-3), are necessary components of the foetal nervous tissues (Huang and Craig-Schmidt, 1996). However levels of these long chain fatty acids in ruminant diets are generally very low and rumen biohydrogenation is extensive (Chikunya et al., 2004), which may limit their availability for incorporation into foetal tissues, especially during the period of rapid foetal growth in late pregnancy. One strategy to enhance the supply of these fatty acids is to supplement diets with fish oils which are rich sources of both AA and DHA. The present study was carried out to evaluate effects of fish oil supplementation and Se- vit. E injection of Egyptian ewes and their Finnish Landrace Crossbred during late stage of pregnancy on behaviors, growth performance and immune status of newborn lambs.

\section{MATERIALS and METHODS}

\section{Animals, housing and diets:}

This study was carried out at Sakha Animal Production Research Station, Animal Production Research Institute, Ministry of Agriculture, Kafr ElSheikh Governorate, Egypt, during the period from August 2010 to April 2011. Fifty-one pregnant ewes [native breeds (Ossimi and Rahmani, $\mathrm{n}=30$ ) and their crosses with exotic Finnish Landrace breed $(n=21)$ ] were experimented in this study. Ewes were synchronized in oestrus using intra-vaginal progesterone sponges (Intervet, Egypt) for 14 days followed by intramuscular injection of 400 IU of PMSG per ewe (Follogon, Intervet, Egypt) on the day of withdrawal sponge, and were naturally inseminated over a 3 day mating period. Pregnancy diagnosis was confirmed by transrectal ultrasonic scanning at day 40 of pregnancy. Ewes were housed in three semi-covered large pens $(6 \mathrm{~m} \times 20 \mathrm{~m}$ of each). Based on breed, age, litter size and live body weight, ewes were divided into 3 equal experimental groups of 17 animals each with a similar mean body weight $(46.6 \mathrm{~kg})$ and age (3.8 years). The first group was fed with a fish oil supplemented diet for 6 weeks prior to lambing (Sardine oil; Arbée Agencies Company, India) at a rate of $40 \mathrm{gm} / \mathrm{ewe} /$ day. The 
second group was received two successive injections of selenium-vitamin E $(5 \mathrm{ml}$ of $2 \mathrm{mg}$ sodium selinate and $100 \mathrm{mg}$ vitamin E) at 20 and 10 days before lambing. The third group was kept as a control.

These ewes were given green fodder (Trifolium Alexandrium) during the green season, hay in the dry one and fresh drinking water. Concentrate mixture was included corn grains $45.3 \%$, decorticated cotton seed $11 \%$, soya bean meal $12 \%$, wheat bran $29 \%$, limestone $1.8 \%, 0.22 \%$ sod. bicarbonate, 0.4 common salt, and $0.28 \%$ mineral mixture. This basal diet contained $15.5 \%$ crude protein and $65 \%$ TDN and was fed to all groups. The diet was provided during pregnancy at a rate of $1 \%$ of average body live weight (500gm daily/ewe). This amount was increased gradually till reach $2 \%$ of average live body weight (1000 gm/ewe) at the late stage of pregnancy (last $4-6$ weeks) and achieved 1250 gm/ewe with their lamb (s) from birth until weaning. Mineral mixture was used as $10 \mathrm{gm}$ per ewe daily. The declared content of selenium in the mineral mixture was $8 \mathrm{ppm}$. Samples from used feeds were analyzed for crude protein, dry matter, ash, ether extract, acid detergent fiber, neutral detergent fiber, and selenium contents according to AOAC (1990) (Table 1). Ankom fibertec apparatus (USA model) was used for fiber analysis. At week $17^{\text {th }}$ of pregnancy, ewes were subcutaneously vaccinated with $2 \mathrm{ml}$ of Clostridia vaccine (Covexin, Schering-Plough Company). Ewes were drenched with an anthelmintic drug (Hapadex, $20 \mathrm{ml} / 50 \mathrm{~kg}$ of body weight, Schering-Plough Company) at start of the experiment and one month after birth. Also, their lambs were drenched with an anthelmintic drug (Baminth, $1 \mathrm{gm} \mathrm{/} 5 \mathrm{~kg}$ of body weight, Pfizer Company).

Lambing occurred in large straw-bedded pens $(6 \times 9$ $\mathrm{m})$, in groups of 8-9 ewes / pen. Ewes were transported to these pens 2 weeks before lambing. Pregnant ewes were accustomed to observer presence as they were regularly checked for signs of parturition from the outside of pen. They were subjected to continuous observation during the last 10-14 days before lambing to ascertain the exact time of birth for each lamb.

\section{Data recording:}

Behavioral observations: The parturition was recorded as the time from the appearance of the first lamb at the vulva to the expulsion of the last lamb. To avoid confounding maternal and behavioral observations, assistance given to ewes during parturition was minimal, consisting of correcting lamb presentation unless the ewe was considered unable to continue without further intervention, and recorded. Neonatal lambs were focal-sampled from expulsion until successful suckling and the latencies of specific behaviors (stand, reach udder and suck) were recorded as Martin and Bateson (1993) by using video camera (Sony, 450X, Shinagawa, Tokyo, Japan). The time from birth to first attempts to stand (lamb on knees, supports part of its weight on at least one foot), stand (lamb supports itself on all 4 feet for at least 5 seconds), reach udder (lamb in parallel inverse position with head nudging ewe in udder region) and successful suck (lamb has teat in its mouth, in correct position, appears to be suckling for at least 5 seconds) were recorded (Dwyer and Lawrence, 1999). Lambs failed to suck within one hr of birth, were assisted and their data were excluded from the study.

Blood assay: within an hour of birth, the lamb was caught and a 3-mL blood sample was taken by jugular venipuncture into heparinized vacutainers before suckling. Rectal temperature was also recorded at this time using clinical thermometers (Mercury thermometers, China). To minimize the disruption to ewe and lamb bonding, all samples were collected within the lambing pen, which allowed the ewe to continue interact with the lamb during sampling, and the sample was collected within few minutes of entering the pen. The blood sampling and temperature recording procedures were repeated at 24 $\mathrm{h}$ after birth. At $72 \mathrm{~h}$ after birth, rectal temperature was recorded too. Before centrifugation, a few drops of each blood sample that collected at $24 \mathrm{~h}$ were used to measure white blood cell (WBC) counts and phagocytic activity according to Wilkinson (1981). The remaining blood samples were centrifuged (3000 rpm for 20 minutes) and the obtained sera were separated and stored at $-20^{\circ} \mathrm{C}$ until assayed for total protein and albumin by spectrophotometer (Spekol 11, Carl Zeiss Jena, Germany) according to the instructions of manufacture (Diagnostic diamond, Egypt, Young, 2001). The concentration of globulin was calculated as the difference between serum total protein and albumin.

Performance measurements: Lamb birth weight was recorded within $24 \mathrm{~h}$ of birth. At weaning (66 days average), lambs were weighed to calculate average daily weight gain. Mortality rates from birth until weaning were recorded.

\section{Statistical analysis:}

Collected data were statistically analysed using SAS version 8.0 (SAS, 2001). All data were compared using ANOVA test and expressed as the Means \pm S.E. The phagocytic activity and mortality rates were tested using a chi-square test and are expressed as a percentage.

\section{RESULTS}

The findings of this study verified that supplementing pregnant ewes with fish oil or selenium-vitamin $E$ improved, in general, vigour, birth weight, and body temperature and immunity status of newborn lambs. 
As shown in table (2), lambs which generally born to supplemented ewes taken less time to stand, reach the udder and suck successfully than those born to control group. The native lambs were more response for these supplements than crossbreds. Lamb's birth weight was increased significantly when ewes supplemented with fish oil and selenium-vitamin E $(3.77 \pm 0.17$ and $3.44 \pm 0.16 \mathrm{~kg}$, respectively, ) than those born to untreated ewes $(2.87 \pm 0.16 \mathrm{~kg}, P<0.01$, figure 1). Within breed, this effect was established only in native ewes $(P<0.01$, figure 2$)$.

There was a significant effect of fish oil and selenium-vitamin E supplementation on lamb rectal temperature through the first hour of life (Table 3 ). This effect was more markedly observed in native breeds $(P<0.01)$ and tended to be present in crossbred ewes $(P<0.06)$. On the contrary, the rectal temperature was similar for treated and untreated ewes and for both breeds at $24 \mathrm{~h}$ old. However, lambs that born to crossbred ewes fed fish oil had greater body temperatures than other lambs at $72 \mathrm{~h}$ of birth $(P<0.01)$.

Maternal fish oil and selenium-vitamin E supplementation had no effect on serum total protein, albumin and globulin of lambs pre-suckling (Table 4). In contrast, after suckling colostrum, total protein $(P<0.04)$ and globulin $(P<0.02)$ concentrations were significantly higher in lambs born by ewes supplemented with selenium-vitamin $\mathrm{E}$ than those born to fish oil and control groups (Table 5). In the same time, these differences were particularly observed in lambs born to crossbred ewes than native breeds (Table 5).

Additionally, total leucocytic count and phagocytic activity were greater in lambs born to ewes supplemented with fish oil and selenium-vitamin $\mathrm{E}$ than those born to control ewes $(P<0.03, P<0.01$, respectively; Table 6). Lambs born by Se-vitamin E supplemented native ewes had higher white blood cells and phagocytic activity percentages than lambs born to fish oil and control groups (Table 6).

Overall analysis revealed that average daily weight gains were greater in lambs reared by ewes treated with selenium-vitamin $\mathrm{E}$ than lambs born to fish oil and untreated ewes, the last had the lowest weightgain $(P<0.01$, Table 7$)$. In both breeds, injection of ewes with selenium-vitamin $E$ increased weight gain of preweaning lambs in compared with those born from fish oil and control groups (Table 7).

In general, low rates of lamb mortality were found in groups supplemented with fish oil or injected selenium-vitamin E during late pregnancy, but these results were significant only in selenium-vitamin $\mathrm{E}$ group compared with other treatments $(P<0.05$, Table $7)$. Within breed analysis revealed that the significant impact was reported only in lambs born to native ewes compared with those born to crossbred ones $(P<0.001$, Table 7$)$.

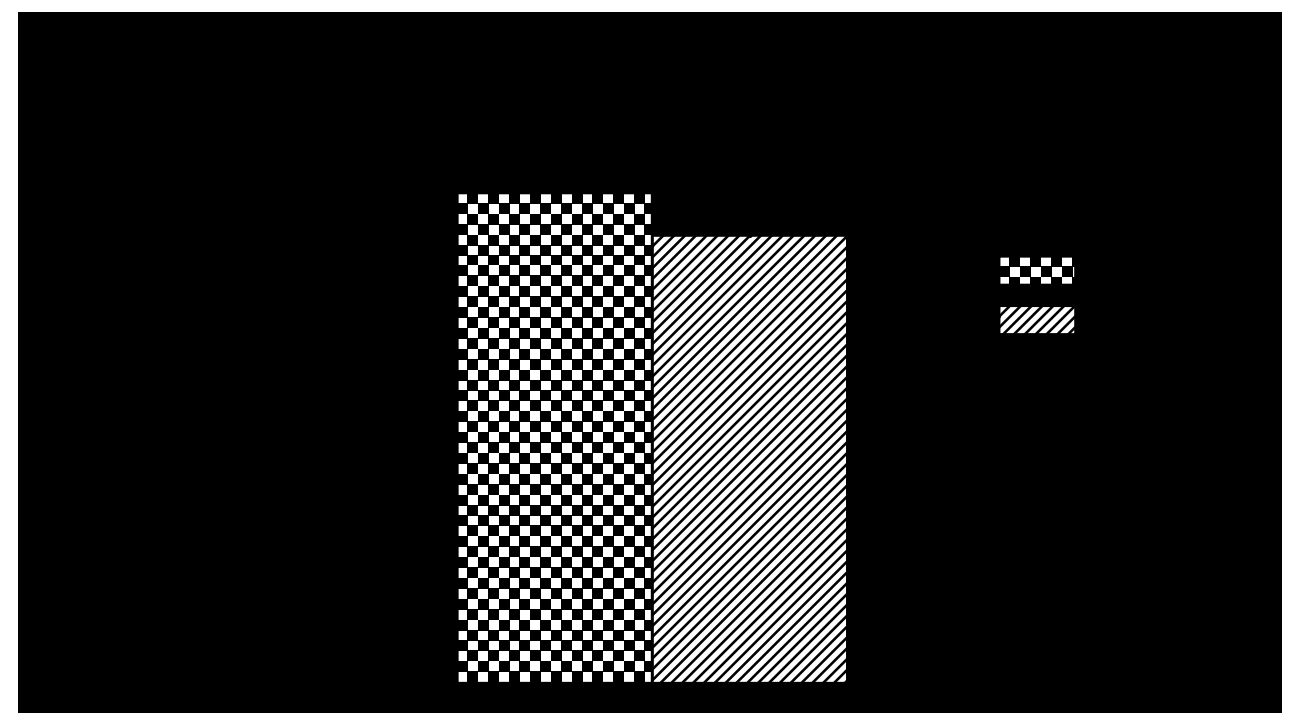

Figure 1: Overall analysis of the effect of fish oil supplementation and selenium-vitamin E injection during late pregnancy on lamb birth weight $(\mathrm{kg})$. 


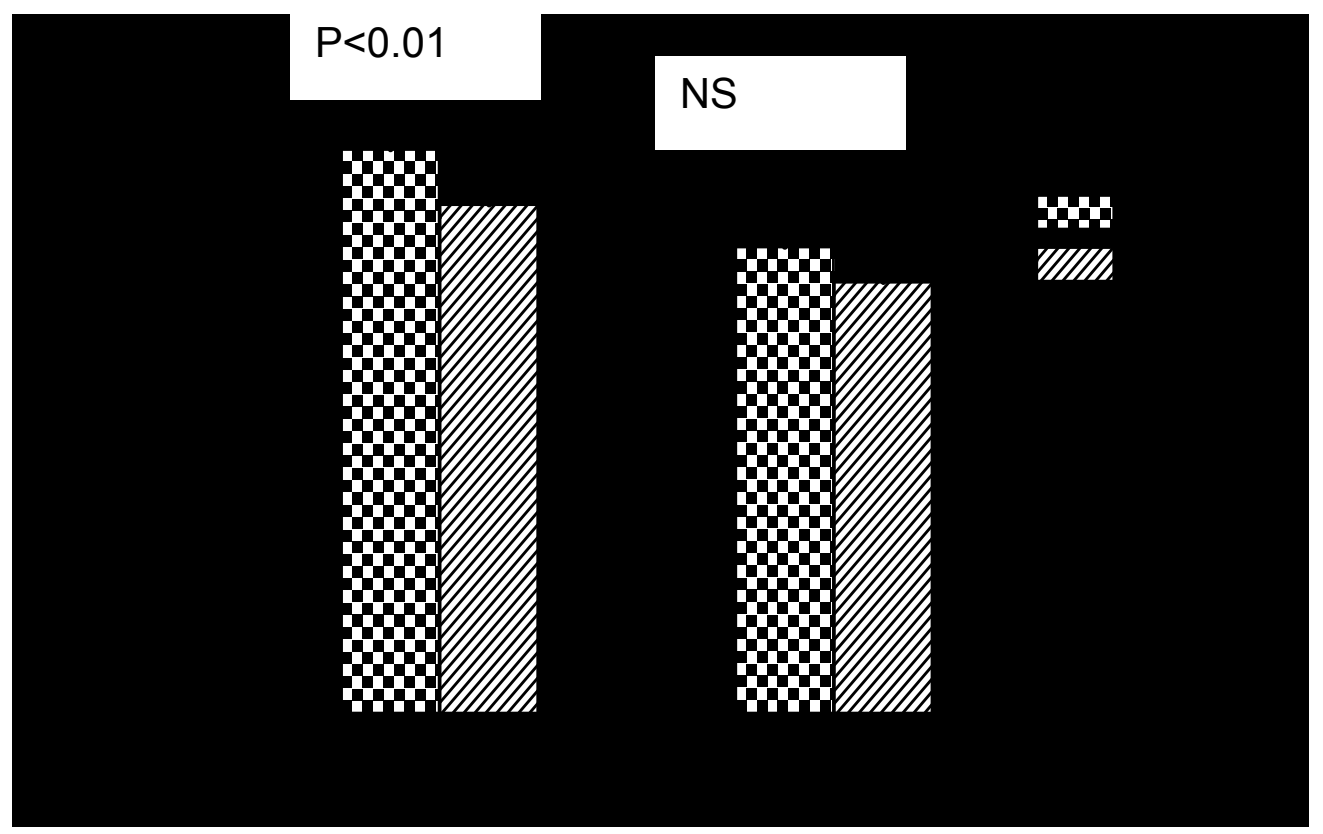

Figure 2: Within breed analysis of the effect of fish oil supplementation and selenium-vitamin E injection uring late pregnancy on lamb birth weight $(\mathrm{kg})$.

Table 1: Chemical composition and nutritive value of used feeds and diets $(\mathrm{gm} / \mathrm{kg})$.

\begin{tabular}{lcccc}
\hline & \multicolumn{2}{c}{ Concentrate mixture } & Trifolium & Hydrolyzed \\
& Control basal diet & Fish oil- supplemented basal diet & & Hay \\
\hline Dry matter & 916 & 913 & 210 & 880 \\
\hline Crude ash & 145 & 144 & 28 & 100 \\
\hline Crude protein & 155 & 153 & 32 & 144 \\
\hline Ether extract & 35 & 72 & 31 & 13 \\
\hline NDF $^{1}$ & 237 & 233 & 395 & 500 \\
\hline ADF $^{2}$ & 115 & 113 & 182 & 390 \\
\hline $\mathrm{TDN}^{3}$ & 650 & 700 & 660 & 630 \\
\hline $\mathrm{Se}(\mathrm{mg} / \mathrm{kg})^{4}$ & 0.08 & 0.08 & 0.01 & 0.34 \\
\hline Vit. E $(\mathrm{mg} / \mathrm{kg})^{5}$ & 25 & 25 & 16 & 125 \\
\hline
\end{tabular}

${ }^{1}$ Neutral detergent fiber

${ }^{2}$ Acid detergent fibers

${ }^{3}$ Total digestible nutrients

${ }^{4}$ Selenium of concentrate mixture was the declared level of added mineral mixture and that of roughages were calculated, however the analyzed content of concentrate mixture was non-detectable level.

${ }^{5}$ Vitamin E content of used feeds as calculated concentrations

Mineral mixture supplies 40 Fe, $6.3 \mathrm{Mn}, 44.9 \mathrm{Zn}, 0.5 \mathrm{Cu}, 0.4 \mathrm{I}, 0.03 \mathrm{Se}, 0.5 \mathrm{Co}, 154 \mathrm{NaCl}$, and $123 \mathrm{Mg}(\mathrm{g} / \mathrm{kg})$ 
$\underline{\text { Assiut Vet. Med. J. Vol. } 59 \text { No. } 138 \text { July } 2013}$

Table 2: Effect of fish oil supplementation and selenium-vitamin E injection during late pregnancy on neonatal lamb behavior.

\begin{tabular}{|c|c|c|c|c|c|}
\hline \multirow{2}{*}{ Behavioural latencies (min) } & & \multicolumn{3}{|c|}{ Treatment } & \multirow{2}{*}{$P$-value } \\
\hline & & Control & Fish oil & Se-Vit. E & \\
\hline \multirow[t]{3}{*}{ Attempt to stand } & Native & $11.37 \pm 2.17^{\mathrm{a}}$ & $3.15 \pm 2.17^{b}$ & $4.11 \pm 2.17^{b}$ & 0.02 \\
\hline & Cross & $10.74 \pm 2.17$ & $4.79 \pm 2.17$ & $5.10 \pm 2.17$ & NS \\
\hline & Overall & $11.05 \pm 1.53^{\mathrm{a}}$ & $3.97 \pm 1.53^{b}$ & $4.60 \pm 1.53^{b}$ & 0.01 \\
\hline \multirow[t]{3}{*}{ Stand } & Native & $16.53 \pm 2.15^{\mathrm{a}}$ & $6.75 \pm 2.15^{b}$ & $9.24 \pm 2.15^{\mathrm{b}}$ & 0.02 \\
\hline & Cross & $14.45 \pm 2.15$ & $8.43 \pm 2.15$ & $8.88 \pm 2.15$ & NS \\
\hline & Overall & $15.49 \pm 1.53^{\mathrm{a}}$ & $7.59 \pm 1.53^{b}$ & $9.06 \pm 1.53^{b}$ & 0.01 \\
\hline \multirow[t]{3}{*}{ Reach udder } & Native & $28.74 \pm 4.33^{\mathrm{a}}$ & $12.23 \pm 4.33^{b}$ & $15.28 \pm 4.33^{b}$ & 0.01 \\
\hline & Cross & $16.19 \pm 4.33$ & $18.07 \pm 4.33$ & $14.73 \pm 4.33$ & NS \\
\hline & Overall & $22.46 \pm 3.07$ & $15.15 \pm 3.07$ & $15.00 \pm 3.07$ & NS \\
\hline \multirow[t]{3}{*}{ Successful suck } & Native & $33.03 \pm 4.38^{\mathrm{a}}$ & $18.10 \pm 4.38^{b}$ & $20.83 \pm 4.38^{\mathrm{ab}}$ & 0.01 \\
\hline & Cross & $20.71 \pm 4.38$ & $23.68 \pm 4.38$ & $21.78 \pm 4.38$ & NS \\
\hline & Overall & $26.87 \pm 3.10$ & $20.89 \pm 3.10$ & $21.30 \pm 3.10$ & NS \\
\hline
\end{tabular}

NS, not significant.

Table 3: Effect of fish oil supplementation and selenium-vitamin E injection during late pregnancy on lamb body temperature $\left(\right.$ in $^{\circ} \mathrm{C}$ ) over the first $3 \mathrm{~d}$ of life (LSMean \pm SE).

\begin{tabular}{|c|c|c|c|c|c|}
\hline \multirow{2}{*}{ Time after birth } & \multirow{2}{*}{ Breeds } & \multicolumn{3}{|c|}{ Treatment } & \multirow{2}{*}{$P$-value } \\
\hline & & Control & Fish oil & Se+vit E & \\
\hline \multirow[t]{3}{*}{$<1 \mathrm{~h}$} & Native & $38.98 \pm 0.20^{b}$ & $39.70 \pm 0.17^{\mathrm{a}}$ & $39.40 \pm 0.20^{\mathrm{ab}}$ & 0.01 \\
\hline & Cross & $38.55 \pm 0.18$ & $39.10 \pm 0.22$ & $38.94 \pm 0.17$ & 0.06 \\
\hline & Overall & $38.76 \pm 0.13^{b}$ & $39.40 \pm 0.14^{\mathrm{a}}$ & $39.17 \pm 0.13^{\mathrm{a}}$ & 0.04 \\
\hline \multirow[t]{3}{*}{$24 \mathrm{~h}$} & Native & $39.01 \pm 0.20$ & $39.20 \pm 0.18$ & $38.97 \pm 0.18$ & NS \\
\hline & Cross & $39.11 \pm 0.19$ & $38.82 \pm 0.21$ & $38.99 \pm 0.16$ & NS \\
\hline & Overall & $39.05 \pm 0.13$ & $39.01 \pm 0.13$ & $38.98 \pm 0.12$ & NS \\
\hline \multirow[t]{3}{*}{$72 \mathrm{~h}$} & Native & $39.12 \pm 0.19$ & $39.45 \pm 0.15$ & $39.15 \pm 0.18$ & NS \\
\hline & Cross & $39.19 \pm 0.13^{b}$ & $39.70 \pm 0.15^{\mathrm{a}}$ & $39.15 \pm 0.13^{b}$ & 0.01 \\
\hline & Overall & $39.15 \pm 0.11^{b}$ & $39.57 \pm 0.10^{\mathrm{a}}$ & $39.14 \pm 0.08^{\mathrm{b}}$ & 0.01 \\
\hline
\end{tabular}

NS, not significant. 
$\underline{\text { Assiut Vet. Med. J. Vol. } 59 \text { No. } 138 \text { July } 2013}$

Table 4: Effect of fish oil supplementation and selenium-vitamin E injection during late pregnancy on serum total protein, albumin and globulin of the pre-suckled lambs (LSMean $\pm \mathrm{SE}$ ).

\begin{tabular}{ccccc}
\hline Items & \multicolumn{3}{c}{ Treatment } & \multirow{2}{*}{$P$-value } \\
\cline { 2 - 4 } & Control & Fish oil & Se+vit E & NS \\
\hline Total protein $(\mathrm{g} / \mathrm{dl})$ & & & $4.65 \pm 0.48$ & $\mathrm{NS}$ \\
\hline Native breeds & $4.03 \pm 0.44$ & $4.39 \pm 0.40$ & $4.05 \pm 0.54$ & $\mathrm{NS}$ \\
\hline Crossbred & $3.22 \pm 0.48$ & $3.03 \pm 0.44$ & $4.35 \pm 0.36$ & $\mathrm{NS}$ \\
\hline Overall & $3.63 \pm 0.33$ & $3.71 \pm 0.30$ & & $\mathrm{NS}$ \\
\hline Albumin (g/dl) & & & $2.23 \pm 0.25$ & $\mathrm{NS}$ \\
\hline Native breeds & $2.21 \pm 0.23$ & $2.23 \pm 0.21$ & $2.42 \pm 0.28$ & $\mathrm{NS}$ \\
\hline Crossbred & $2.11 \pm 0.25$ & $1.85 \pm 0.23$ & $2.33 \pm 0.19$ & $\mathrm{NS}$ \\
\hline Overall & $2.16 \pm 0.17$ & $2.04 \pm 0.16$ & & $\mathrm{NS}$
\end{tabular}

Table 5: Effect of fish oil supplementation and selenium-vitamin E injection during late pregnancy on serum total protein, albumin and globulin of lambs at $24 \mathrm{~h}$ of birth (LSMean \pm SE).

\begin{tabular}{llcccc}
\hline \multirow{2}{*}{ Items } & \multirow{2}{*}{ Breeds } & \multicolumn{3}{c}{ Treatment } & $\begin{array}{c}P \text { - } \\
\text { value }\end{array}$ \\
\cline { 3 - 6 } & & Control & Fish oil & Se+vit E & 0.03 \\
\hline Total protein $(\mathrm{g} / \mathrm{dl})$ & Native & $6.00 \pm 0.36^{\mathrm{b}}$ & $6.36 \pm 0.36^{\mathrm{ab}}$ & $7.11 \pm 0.38^{\mathrm{a}}$ & 0.01 \\
\hline & Cross & $4.11 \pm 0.34^{\mathrm{b}}$ & $4.61 \pm 0.36^{\mathrm{ab}}$ & $5.27 \pm 0.34^{\mathrm{a}}$ & 0.04 \\
\hline Albumin $(\mathrm{g} / \mathrm{dl})$ & Native & $5.06 \pm 0.25^{\mathrm{b}}$ & $5.49 \pm 0.25^{\mathrm{b}}$ & $6.20 \pm 0.26^{\mathrm{a}}$ & $\mathrm{NS}$ \\
\hline & Cross & $2.29 \pm 0.19$ & $2.49 \pm 0.19$ & $2.46 \pm 0.20$ & 0.04 \\
\hline Globulin $(\mathrm{g} / \mathrm{dl})$ & Native & $2.81 \pm 0.18^{\mathrm{a}}$ & $2.27 \pm 0.19^{\mathrm{b}}$ & $2.38 \pm 0.18^{\mathrm{ab}}$ & $\mathrm{NS}$ \\
\hline & Cross & $2.56 \pm 0.13$ & $2.38 \pm 0.19$ & $2.42 \pm 0.14$ & 0.05 \\
\hline & Overall & $3.71 \pm 0.33^{\mathrm{b}}$ & $3.87 \pm 0.33^{\mathrm{ab}}$ & $4.65 \pm 0.35^{\mathrm{a}}$ & 0.01 \\
\hline
\end{tabular}

NS, not significant

Table 6: Effect of fish oil supplementation and Se-vitamin E injection during late pregnancy on white blood cell counts (per $\mathrm{cmm})$ and phagocytic activity $(\%)($ LSMean \pm SE).

\begin{tabular}{llcccc}
\hline \multirow{2}{*}{ Items } & \multirow{2}{*}{ Breeds } & \multicolumn{3}{c}{ Treatment } & $\begin{array}{c}P- \\
\text { value }\end{array}$ \\
\cline { 3 - 5 } & & Control & Fish oil & Se-Vit. E & 0.02 \\
\hline WBCs & Native & $5550.00 \pm 669.85^{\mathrm{b}}$ & $6625.00 \pm 669.85^{\mathrm{b}}$ & $8920.00 \pm 733.79^{\mathrm{a}}$ & 0.032 \\
\hline & Cross & $5700.00 \pm 947.32$ & $8383.33 \pm 947.32$ & $6825.00 \pm 947.32$ & NS \\
\hline Phagocytosis & Native & $5625.00 \pm 580.11^{\mathrm{b}}$ & $7504.17 \pm 580.11^{\mathrm{a}}$ & $7872.50 \pm 599.14^{\mathrm{a}}$ & 0.03 \\
\hline & Cross & $71.67 \pm 3.51^{\mathrm{b}}$ & $90.33 \pm 3.25^{\mathrm{ab}}$ & $92.67 \pm 3.51^{\mathrm{a}}$ & 0.03 \\
\hline & Overall & $79.50 \pm 2.29^{\mathrm{b}}$ & $89.00 \pm 2.29^{\mathrm{a}}$ & $91.33 \pm 2.29^{\mathrm{a}}$ & 0.01 \\
\hline
\end{tabular}

NS, not significant 
Table 7: Effect of fish oil supplementation and selenium-vitamin E injection during late pregnancy on weight gain $(\mathrm{kg})$ and mortality rate $(\%)$ of lambs (LSMean \pm SE).

\begin{tabular}{llcccc}
\hline \multirow{2}{*}{ Items } & Breeds & \multicolumn{3}{c}{ Treatment } & $\begin{array}{c}P- \\
\text { value }\end{array}$ \\
\cline { 3 - 5 } Weight gain & Native & Control & Fish oil & Se + Vit. E & 0.05 \\
\hline & Cross & $0.156 \pm 0.01^{\mathrm{b}}$ & $0.180 \pm 0.01^{\mathrm{ab}}$ & $0.199 \pm 0.01^{\mathrm{a}}$ & 0.01 \\
\hline & Overall & $0.123 \pm 0.01^{\mathrm{b}}$ & $0.156 \pm 0.01^{\mathrm{b}}$ & $0.203 \pm 0.01^{\mathrm{a}}$ & 0.01 \\
\hline Mortality rate* & Native & $0.140 \pm 0.01^{\mathrm{c}}$ & $0.169 \pm 0.01^{\mathrm{b}}$ & $0.201 \pm 0.01^{\mathrm{a}}$ & 0.01 \\
\hline & Cross & $14.3 \%$ & $13.3 \%$ & $0.0 \%$ & 0.001 \\
\hline & Overall & $7.7 \%$ & $8.3 \%$ & $7.1 \%$ & NS \\
\hline
\end{tabular}

Values carrying different letters are significantly different. NS, not-significant

*Chi-square test

\section{DISCUSSION}

Poor lamb survival following maternal under dietary supplements during pregnancy is a probable consequence of a lower lamb birth-weight, leading to impaired thermoregulatory ability and reduced neonatal immunocompetence expression (Moor et al., 1986; Dwyer and Morgan 2006). The aim of the present study was to improve the immunity status of the neonatal lambs with a view to beneficially modifying behaviour, which may compound the enhanced survivability of the lamb. The current data demonstrated that lambs born to ewes fed on diets supplemented with fish oil or injected with seleniumvitamin E. In addition, they had little time to stand and reach udder more than those of control one, were heavier and had greater rectal temperatures than those born to untreated ewes. The most important determinanted of neonatal lamb immunocompetence is the consumption of colostrum because newborns are essentially devoid of immunoglobulins (Perino and Rupp, 1994). Therefore, the injection of selenium-vitamin $\mathrm{E}$ to pregnant ewes increases immunoglobulin in their colostrums that reflect on the level of globulin in newborn lambs following suckling. In addition, both fish oil supplementation and selenium-vitamin $\mathrm{E}$ injection cause an increase in the number of circulating leucocytes and phagocytosis percent.

Improvement birth weight of lambs may be attributed to the long gestation length (Baguma-Nibasheka et al., 1999; Mahboub et al., 2012). Since a relationship between fetal growth rates and gestation length was existed, as demonstrated by Rattray et al. (1974) who stated that fetal growth rates during the late stage of pregnancy were $0.15-0.2 \mathrm{~kg} / \mathrm{day}$. This increase in gestation length may be resulted in a physiologically more mature lamb at parturition. There are many attempts have been made to identify the effectiveness of fish oil and selenium-vitamin $\mathrm{E}$ supplementation on lamb birth weight, but the results have been inconsistent. For instance, Capper et al. (2005); Koyuncu and Yerlikaya (2007); El-Shahat and Abdel Monem (2011) reported that ewes supplemented with vitamin $\mathrm{E}$ and/or selenium had lambs with significantly higher weight at birth. However, Williamson et al. (1995) and Kott et al. (1998) found no differences in birth weight of lambs born to either ewes supplemented before lambing with vitamin E or not. Moreover, Gabryszuk and Klewiec (2002) indicated that selenium-vitamin E supplementation had a negative impact on live weight at birth in lambs of 2 years old dams. Furthermore, Capper et al. (2006) and Annett et al. (2008) showed that birth weights of lambs born to ewes that were supplemented with fish oil during pregnancy were not significantly differed from those born to control ewes. In this respect, the differences of lamb birth weight may be attributed to genotype (Maiorano et al., 1999; Hatfield et al., 2000) and age of animals that resulted in variation in energy, selenium and vitamin $\mathrm{E}$ requirements. The mechanism by which vitamin $\mathrm{E}$ may increase birth weight and growth rate is unknown.

The latencies of neonatal behaviors observed in the current study agree with those reported previously by Pickard et al. (2005) and Capper et al. (2006). The supplementation of fish oil and injection seleniumvitamin $\mathrm{E}$ during late pregnancy significantly reduced the latencies of progress from standing to successful suckling in neonatal lambs. It was postulated that delays in suckling, in control group, may be due in part to myopia, which reduces the ability of the lamb to successfully locate the udder (O'Connor and Lawrence, 1992). Studies in humans related improved visual acuity, cognitive development, and motor skills during infancy to the intake of $(n-3)$ PUFA, specifically 22:6 (n-3), before weaning, suggesting that supplementation with these fatty acids improves neural development (Birch et al., 2002; 
Bouwstra et al., 2003). Similarly, learning behavior was improved in rats (Ikemoto et al., 2001) and pigs $(\mathrm{Ng}$ and Innis, 2003) by (n-3) fatty acid supplementation, these findings support the our results. Consequently, fish oil has high contents of long-chain polyunsaturated fatty acids (PUFA) especially arachidonic acid (AA) and docosahexaenoic acid (DHA) and their precursors (linoleic acid and $\alpha$-linolenic acid) (Kitessa et al., 2003) that are essential for neural tissue development within the neonatal and sucking animal (Huang and Craig-Schmidt, 1996; Boure, 2005). With regard to selenium-vitamin E supplementation, it was reported that lambs born by ewes supplemented with vitamin E during pregnancy stand and suckle faster than those born by control ewes (Merrell, 1998) and thus have an increased greater viability (Williamson et al., 1995). Benefits of vitamin E supplementation on neonatal behaviour would therefore appear to be most likely when oxidative challenge is greatest. Another influencing factor may have been the birth weight where heavy lambs were quicker to suck than light lambs (Dwyer and Morgan, 2006). So improving lamb birth weight as demonstrated in this study with fish oil or selenium-vitamin E supplementation is more likely important to enhance neonatal behavioral progress (Mellor and Murry, 1985b).

Immediately after birth, lamb has a high metabolic turnover which may increase body temperature (Symonds et al., 1995). Before colostrum ingestion, new born lamb depends solely on its brown fat energy reserves to maintain body temperature. Large neonates have more available brown fat $/ \mathrm{kg}$ of body weight than small ones, and hence giving them a more chance to maintain homeothermy (Sykes, 1982; Dwyer and Morgan, 2006). Behavioral capability and body temperature appear to be linked; lambs with a normal rectal temperature are more likely to reach the udder quicker than those with low temperatures (Slee and Springbett, 1986). Thus, behavioral mechanisms may operate to prevent falls in body temperature. Standing rapidly after birth may help the wet lambs to reduce convective heat loss to the ground, as well as sucking bouts raises their body temperature (Bird et al., 2001). Therefore the rapid behavioral progress of the lambs born to ewes treated with fish oil or injected selenium-vitamin E compared with lambs born to untreated ewes and of the heavier lambs compared with low birth weight lambs seen in the current study will have contributed directly to their greater temperatures. In addition, ewes supplemented with fish oil and selenium-vitamin E produced large lambs that have a less surface area to weight ratio thus they are more resistant to hypothermia after birth because of low rate of heat loss per unit of body weight (Sykes et al., 1976). Conversely, the significant difference between groups was disappeared at $24 \mathrm{~h}$ of birth and returned to be present at $72 \mathrm{~h}$ of birth $(P<0.01)$, with an improve in the body temperature of lambs born to control ewes during this period ( at 24 and $72 \mathrm{~h}$ of birth) compared with their pre-suckling temperatures. This may be attributed to the absence of significant differences in colostrum composition between treated and untreated ewes, as previously demonstrated (Rashid et al., 2010; Mahboub et al., 2012).

Breed differences in body temperature in response to fish oil and selenium-vitamin E supplementation were recorded in this study. Certainly, breed differences in ability to maintain body temperature over the first three days of life and genetic variation in this trait within breed have been studied before (Sykes et al., 1976; Slee and Springbett, 1986; Slee et al., 1991). Crossbred supplemented ewes produced smaller lambs than native ewes and would be expected to lose heat more quickly. Consequently, native lambs were more successful at maintaining body temperature than crossbred lambs. This indicates that the native lambs were either more efficient at conserving heat through better coat or tissue insulation or were more efficient at producing heat than crossbred lambs or both. It is possible that the differences in ability to maintain body temperature between the native and crossbreds seen here, in addition to rapid behavioral progress recorded in native lambs, were a result of differences in the rate of development of cold thermogenesis after birth (Sykes et al., 1976).

Lambs are born antibody deficient and have comprised immune systems until they ingest colostrums. This is obvious in pre-suckling stage where lambs had low levels of globulin in compared to post-suckled lambs. Otherwise, maternal fish oil and selenium-vitamin E supplementation had no effects on serum total protein, albumin and globulin concentrations in the pre-suckled neonatal lambs indicating inefficient placental transfer. This may be attributed to the physiological selectivity of the placental barrier that, may exclude these particles due to their molecular size (Eales and Small, 1995). In contrast, lamb serum globulin concentrations were increased considerably following colostrum intake indicating efficient mammary gland transfer. In addition, hematological analysis revealed significantly higher white blood cell counts and phagocytic activity in lambs born to treated ewes than lambs born to control ones. Gershwin et al. (1985) and Johnston $(1985 ; 1988)$ found that both cellmediated immunity and humoural immunity are influenced by the amount and the type of fat in the diet. Since n-3 PUFAs that found in fish oil reduce tissue levels of immune suppressive agents therefore increased intake of n-3 PUFAs may enhance immune responses (Fritsche et al., 1991; Hwang, 2000). In sheep, selenium and/or vitamin $\mathrm{E}$ can increase antibody production against different antigens (Giadinis et al., 2000) and also can improve the 
cellular immune response (Suttle and Jones, 1989; Turner and Finch, 1990). Karen and David (1996) stated that vitamin $\mathrm{E}$ and selenium deficiency reduced phagocytic activity by polymorphonuclear neutrophil leukocytes from peripheral blood. In contrast, Annett et al. (2009) reported that fish oil did not significantly affect lamb serum IgG concentration at birth.

These findings were more particularly evident in lambs born to native ewes injected with seleniumvitamin E compared with those born to other groups. However, fish oil and selenium-vitamin E supplementations had similar effects on crossbred ewes through increasing serum globulin levels and phagocytic activity in their lambs. This diversity in response to fish oil and selenium-vitamin $\mathrm{E}$ supplementation between native and crossbred ewes may be attributed to breed differences that were obvious in untreated groups too. Pre-sucking, lambs born to untreated native ewes have numerically higher globulin concentrations than lambs born to crossbred ones.

Compared to the control group, a combined selenium-vitamin $\mathrm{E}$ had a more positive impact on lamb daily weight gain $(P<0.01)$ (Koyuncu and Yerlikaya, 2007; El-Shahat and Abdel Monem, 2011). However, some studies demonstrated no effect on lamb body weight gain with either vitamin $\mathrm{E}$ (Williamson et al., 1995; Fry et al., 1996) or selenium and vitamin E supplementation (Appeddu et al., 1994). But supplementing ewes with fish oil at late pregnancy improve weight gain of their lambs numerically. These results disagree with Annett et al. (2008) who reported that neither lamb weaning weight nor daily weight gain were influenced by fish oil supplementation to the ewe in late gestation. Selenium-vitamin E supplementation enhances the levels of selenium and vitamin $\mathrm{E}$ and may indirectly improve lamb performance (Sobiech and Kuleta, 2002) and strengthening its immunity status (Milad et al., 2001). Therefore, improvement of weight gain of lambs from birth till weaning in selenium-vitamin E groups may be attributed to increased immunocompetence and decreased susceptibility of lambs to deficiency diseases. In this study, both native and crossbred ewes were responding to supplementation, specifically with selenium-vitamin E.

Neonate mortality remains a welfare concern for sheep productivity. In order to maintain profitability, it is therefore vital to minimize lamb mortality and maximize lamb growth rate. A major factor in mortality is hypothermia due to delayed suckling and exhaustion of brown fat reserves (Slee, 1981). Lambs that are vigorous at birth with a short latency of standing and suckling may therefore be more likely to survive during the perinatal period. Supplementation of pregnant ewes with fish oil or selenium-vitamin E improves body temperatures and neonatal behavioral progress of their lambs as that recorded in this study. Consequently, low mortality rates were recorded in lambs born to ewes treated with fish oil and selenium-vitamin E compared to untreated ones. Additionally, decrease lamb mortality may be attributed to improved birth weight where increasing birth weight of lambs with such supplementation is negatively correlated with mortality rates (Dwyer, 2003), and impaired lamb survival is associated with slow to stand and suck after birth (Darwish et al., 2010; Darwish and Ashmawy, 2011). Moreover, weak lambs with low birth mass were unable to suckle a sufficient amount of colostrum, and as a result the immunoglobulins level in their serum was low. The physical weakness and low immunoglobulins led to increased mortality in lambs with a low birth mass (Ahmad et al., 2000). Supplementation of pregnant ewes with selenium may reduce lamb mortality (Muñoz et al., 2008), although other studies suggest no effect on survival. Supplementation with vitamin $\mathrm{E}$ and/or fatty acids are also considered to improve lamb survival, and reduce the time taken by lambs to reach the udder and suckle (Williamson et al., 1996; Capper et al., 2005, 2006). Moreover, Segerson et al. (1986) and ElShahat and Abdel Monem (2011) indicated that the mean number of lambs weaned per ewe lambing were $1.1,1.5$ respectively for ewes treated with seleniumvitamin E and control ewes. However, Gentray et al. (1992) and Williamson et al. (1996) reported that there was no influence of vitamin $E$ injection to the ewe on lamb mortality. With respect to fish oil supplementation, Rashid et al. (2010) showed that lambs born to fish oil supplemented ewes had greater plasma content of EPA and DHA than lambs born to the control ewes, which may have a beneficial effect on lamb survival rate through increased gestation length or enhanced neural tissue development or both. Although, Capper et al. (2002) and Annett et al. (2008) demonstrated no evidence of a lamb survival benefit due to fish oil supplementation.

\section{CONCLUSION}

The results of the current study show that supplementing ewes with selenium-vitamin $\mathrm{E}$ and to some extent fish oil during late pregnancy has the potential to increase lamb birth weight, reduced the latencies to stand and suckle and improved immune function of neonatal lambs. This could be resulted in enhance lamb performance and reduced lamb mortality. The response to these nutrient supplements is more pronounced in native breeds than crossbreds. Generally, lamb should be encouraged to nurse as soon as possible to maximize absorption of immunoglobulins from colostrum. 


\section{ACKNOWLEDGEMENTS}

This project was supported financially by the Science and Technology Development Fund (STDF), Egypt, Grant No. 736

\section{REFERENCES}

Ahmad, R.; Khan, A.; Javed, M.T. and Hussain, I. (2000): The level of immunoglobulins in relation to neonatal lamb mortality in PakKarakul sheep. Vet arhiv 70, 129-139.

Annett, R.W.; Carson, A.F. and Dawson, L.E.R. (2008): Effects of digestible undegradable protein (DUP) supply and fish oil supplementation of ewes during late pregnancy on colostrum production and lamb output. Animal Feed Science and Technology, Volume 146, Issues 3-4, Pages 270-288.

Annett, R.W.; Dawson, L.E.R.; Edgar, H. and Carson, A.F. (2009): Effects of source and level of fish oil supplementation in late pregnancy on feed intake, colostrum production and lamb output of ewes. Animal Feed Science and Technology 154: 169-182.

$A O A C$, International, (1990): Official Methods of Analysis. 15th ed. AOAC Int., Washington, DC.

Appeddu, L.A.; Ely, D.G.; Aaron, D and K., Deweese, W.P. (1994): Response of lactating ewes to unjections of selenium and vitamin E. A. Anim. Sci., 722: p. 11.

Baguma-Nibasheka, M.; Brenna, J.T. and Nathanielsz, P.W. (1999): Delay of pre-term delivery in sheep by omega-3 long-chain polyunsaturates. Biol Reprod.; 60: 698-701.

Bell, A.W. (1995): Regulation of organic nutrient metabolism during transition form late pregnancy to early lactation. J. Anim. Sci., 73: 2804- 2819

Birch, E.E.; Hoffman, D.R.; Castañeda, Y.S.; Fawcett, S.L.; Birch, D.G. and Uauy, R.D. (2002): A randomized controlled trial of longchain polyunsaturated fatty acid supplementation of formula in term infants after weaning at $6 \mathrm{wk}$ of age. Am J Clin Nutr., 75: 570-80.[Abstract/Free Full Text]

Bird, J.A.; Mostyn, A.; Clarke, L.; Juniper, D.T.; Budge, H.; Stephenson, T. and Symonds, M.E. (2001): Effect of postnatal age anti a beta (3)adrenergic agonist (Zeneca D7114) administration on uncoupling protein-1 abundance in the lamb. Exp. Physiol. 86: 65-70.

Boure, J.M. (2005): Effect of increasing the omega-3 fatty acid in the diets of animals on the animal products consumed by humans. Med. Sci. 21: 773-779.

Bouwstra, H.; Dijck-Brouwer, D.A.J.; Wildeman, J.A.L.; Tjoonk, H.M.; Van der Heide, J.C.;
Boersma, E.R.; Muskiet, F.A.J. and HaddersAlgra, M. (2003): Long chain polyunsaturated fatty acids have a positive effect on the quality of general movements of healthy term infants. Am J Clin Nutr.; 78: 313-8.

Brambell, F.W.R. (1970): The transmission of passive immunity from mother to young. In Frontiers of biology, vol. 18, p. 166. North Holland Publishing Co., Amsterdam.

Capper, J.L.; Wilkinson, R.G.; Kasapidou, E.; Pattinson, S.E.; Mackenzie, A.M. and Sinclair, L.A. (2005): The effect of dietary vitamin $\mathrm{E}$ and fatty acid supplementation of pregnant and lactating ewes on placental and mammary transfer of vitamin $\mathrm{E}$ to the lamb. Br J Nutr. Apr; 93 (4): 549-57.

Capper, J.L.; Wilkinson, R.G.; Sinclair, L.A.; Pattinson, S.E. and Mackenzie, A.M. (2002): The effect of long-chain polyunsaturated fatty acid and vitamin E supplementation of ewes on neonatal lamb vigour, lamb growth and colostrum parameters. Proc. Br. Soc. Anim. Sci., p.7.

Capper, J.L.; Robert, R.G.; Wilkinson, G.; Mackenzie, A.M. and Sinclair, L.A. (2006): Polyunsaturated Fatty Acid Supplementation during Pregnancy Alters Neonatal Behavior in Sheep. J. Nutr., 136: 397-403.

Chikunya, S.; Demirel, G.; Enser, M.; Wood, J.D.; Wilkinson, R.G. and Sinclair, L.A. (2004): Biohydrogenation of dietary n-3 PUFA and stability of ingested vitamin $\mathrm{E}$ in the rumen, and their effects on microbial activity in sheep. Brit. J. Nutr. 91, 539-550.

Christley, R.M.; Morgan, K.L.; Parkin, T.D.H. and French, N.P. (2003): Factors related to the risk of neonatal mortality, birth-weight and serum immunoglobulin concentration in lambs in the UK. Preventive Veterinary Medicine; 57: 209 -226.

Darwish, R.A.; Abou-Ismail, U.A. and El-Kholya, S.Z. (2010): Differences in post- parturient behaviour, lamb performance and survival rate between purebred Egyptian Rahmani and its crossbred Finnish ewes. Small Rum Res; 89: 57-61.

Darwish, R.A. and Ashmawy, T.A.M. (2011): The impact of lambing stress on post-parturient behaviour of sheep with consequences on neonatal homeothermy and survival. Theriogenology 76: 999-1005.

Dawson, L.E.R.; Carson, A.F. and Kilpatrick, D.J. (1999): The effect of digestible undegradable protein concentration of concentrates and protein source offered to ewes in late pregnancy on colostrum production and lamb performance. Anim. Food. Sci. Technol., 82: 21- 36.

Dwyer, C.M. (2003): Behavioural development in the neonate lamb: effect of maternal and birth 
related factors. Theriogenology, 59: 10271050.

Dwyer, C.M. and Lawrence, AB. (1999): Does the behaviour of the neonate influence the expression of maternal behaviour in sheep? Behaviour.136: 367-89

Dwyer, C.M. and Morgan, C.A. (2006): Maintenance of body temperature in the neonatal lamb: Effect of breed, birth weight and litter size. Journal of Animal Science, May; 84 (5): 1093.

Eales, F.A. and Small, J. (1995): Practical lambing and lamb care. Longman, Singapore publishers Pte Ltd.

El-Raies, S.A.A. (2001): Selenium presence and behaviour in soil and plant.1-Sein Giza governorate, Egypt .J. Agric. Sci. Mansoura Univ.,26: 5855-5861.

El-Shahat, K.H. and Abdel Monem, U.M. (2011): Effects of Dietary Supplementation with Vitamin E and /or Selenium on Metabolic and Reproductive Performance of Egyptian Baladi Ewes under Subtropical Conditions. World Applied Sciences Journal 12 (9): 1492-1499.

Everett-Hincks, J.M.; Lopez-Vilalobos, N.; Blair, H.T. and Stafford, K.J. (2005b): The effect of maternal behavior score on Iamb and litter survival. Livest. Prod. Sci. 93: 51-61.

Fritsche, K.L.; Cassity, N.A. and Huang, S.C. (1991): Effect of dietary fat source on antibody production and lymphocyte proliferation in chickens. Poult. Sci., 70, pp. 611-617

Fry, J.M.; McGrath, M.C.; Harvey, M.; Sunderman, F.; Smith, G.M. and Speijers, E.J. (1996): Vitamin E treatment of weaner sheep. I. The effect of vitamin E supplements on plasma $\alpha$ tocopherol concentraitons, liveweight, and wool production in penned or grazing sheep. Aust. J. Agric. Res. 47: 853-867.

Gabryszuk, M. and Klewiec, J. (2002): Effect of injecting 2-and 3-year-old ewes with selenium and selenium-vitamin $\mathrm{E}$ on reproduction and rearing of lambs. Small Ruminant Research, Volume 43, Issue 2, Pages 127-132.

Gentray, P.C.; Ross, T.T.; Oetting, B.C. and Birch, K.D. (1992): Effects of supplemental $\mathrm{d}-\alpha-$ tocopherol on preweaning lamb performance, serum and colostrum tocopherol levels and immunoglobulin G titers. Sheep Res. J. 8: 95-100.

Gershwin, M.E.; Beach, R.S. and Hurley, L.S. (1985): Lipids. Nutrition and Immunity. Academic Press, Inc., Orlando, FL, pp. 259-284.

Giadinis, N.; Koptopoulos, G.; Roubies, N.; Siarkou, $V$. and Papasteriades, A. (2000): Selenium and vitamin $E$ effect on antibody production of sheep vaccinated against enzootic abortion (Chlamydia psittaci). Comparative Immunol. Microbio. Inf. Dis. 23: 129-137.
Gubernick, D.J. (1981): Parent and infant attachment in mammals, parent care in mammals. Plenum, New York, pp. 243-305.

Hatfield, P.G.; daniels, J.T.; Kott, R.W.; Burgess, D.E. and Evans, T.J. (2000): Role of supplemental vitamin $\mathrm{E}$ in lamb survival and production: a review. Retrieved December 12, 2005, from American Society of Animal Science Website.

Hodgson, J.C.; Moon, G.M.; Hay, L.A. and Quirie, M. (1992): Effectiveness substitute colostrum in preventing disease in newborn lambs. Occasional Publication, British Society of Animal Production 15, 163-165.

Huang, M. and Craig-Schmidt, M.C. (1996): Arachidonate and docosahexaenoate added to infant formula influence fatty acid composition and subsequent eicosanoid production in neonatal pigs. J. Nutr. 126: pp. 2199-2208.

Hwang, D. (2000): Fatty acids and immune response: a new perspective in searching for clues to mechanism. Annu. Rev. Nutr. 20, 431-456.

Ikemoto, A.; Ohishi, M.; Sato, Y.; Hata, N.; Misawa, Y.; Fujii, Y. and Okuyama, H. (2001): Reversibility of n-3 fatty acid deficiencyinduced alterations of learning behavior in the rat: level of n-6 fatty acids as another critical factor. J Lipid Res. 42: 1655-63.

Johnston, P.V. (1985): Dietary fat, eicosanoids, and immunity Adv. Lipid Res., 21 (1985), pp. 37-86

Johnston, P.V. (1988): Lipid modulation of immune responses. In: Chandra, R.K. (Ed.), Nutrition and Immunology. Alan R. Liss, Inc., New York, pp. 37-86.

Karen, S.K. and David, N.M. (1996): Nutrition and the Immune System: A Review of NutrientNutrient Interactions. Journal of the American Dietetic Association., 96 (11): 1156-1164.

Kitessa, S.M.; Peake, D.; Bencini, R. and Williams, A.J. (2003): Fish oil metabolism in ruminants III. Transfer of n-3 polyunsaturated fatty acids (PUFA) from tuna oil into sheep's milk. Anim. Feed Sci. Technol. 108: 1-14.

Kott, R.W.; Thomas, V.M.; Hatfield, P.G.; Evans, T. and Davis, K.C. (1998): Effects of dietary vitamin $E$ supplementation during late pregnancy on lamb mortality and ewe productivity. J AM Vet Assoc. Apr 1; 212(7): 997-1000.

Koyuncu, M. and Yerlikaya, H. (2007): Effect of selenium-vitamin $\mathrm{E}$ injection of ewes on reproduction and growth of their lambs. S. Afr. J. Anim. Sci., 37: 233-236.

Mahboub, H.D.H.; Ragab, A.D.; Mabrouk, A.A.; ElKholya, S.Z.; Said, I.F. and Ashmawy, T.A.M. (2012): Fish oil and selenium-vitamin E supplementation of Egyptian sheep and its Finnish Landrace crossbred during late 
pregnancy: Ewe response. Proceeding of the 7th scientific conference, 24-27 April, Menoufia University, Sadat city branch, p. 147-162.

Maiorano, G.; Manchisi, A.; salvatori, G.; Filetti, F. and Oriani, G. (1999): Influence of multiple injections of vitamin $\mathrm{E}$ on intramuscular collagen and bone characteristics in suckling lambs. Journal of Animal Science, Volume 77: pp. 452-2457.

Martin, P. and Bateson, P. (1993): Measuring behaviour. Cambridge University Press. Cambridge, UK: Press Syndicate of the University of Cambridge.

Mc Giure, T.C.; Regnier, J.; Kellom, T. and Gates, $N$. (1983): Failure in passive transfer of immunoglobulin G1 to lambs: measurement of immunoglobulin G1 in ewe colostrums. Am J Vet Res., 44 (6): 1064-7.

Mellor, D.J. and Murry, L. (1985): Effects of maternal nutrition on the availability of energy in the body reserves of fetuses at term and in colostrum from Scottish Black-face ewes with twin lambs. Research in Veterinary Science, 39: 235-240.

Mellor, D.J. Murray, L. (1986): Making the most of colostrum at lambing. Vet. Rec. 118: 351-353.

Merrell, B.G. (1998): The effects on lamb survival rate of supplementing ewes with vitamin $\mathrm{E}$ during late pregnancy. Sheep Vet. Soc. Proc., 22: 57-61.

Milad, K.; Racz, O. and Sipulova, A. (2001): Effect of vitamin $\mathrm{E}$ and selenium on blood glutathione peroxidase activity and some immunological parameters in sheep. Vet. Med. Czech., 46: 1-5.

Moore, R.W.; Millar, C.M. and Lynch, P.R. (1986): The effects of prenatal nutrition and type of birth and rearing of lambs on vigour, temperature and weight at birth, and weight and survival at weaning. Proc. N.Z. Soc. Anim. Prod. 46, 259-262.

Munoz, C.; Carson, A.F.; McCoy, M.A.; Dawson, L.E.R.; O'Connell, N. E. and Gordon, A.W. (2008): Nutritional status of adult ewes during early and mid-pregnancy. 2. Effects of supplementation with selenised yeast on ewe reproduction and offspring performance to weaning. Animal, 2:1, pp 64-72.

Mutassim, M.A. (2007): The effect of high calcium intake by pregnant Awassi ewes at late gestation on minerals status and performance of ewes and newborn lambs. Livestock Science, 117: 15- 23.

Ng, K.G. and Innis, SM. (2003): Behavioral responses are altered in piglets with decreased frontal cortex docosahexaenoic acid. J Nutr.; 133: 3222-7.

Nowak, R. and Lindsay, D.R. (1990): Effect of genotype and litter size on discrimination of mothers by their twelve-hour old lambs. Behaviour, 115: 1-13.

O'Connor, CE. and Lawrence, AB. (1992): Relationship between lamb vigour and ewe behaviour at parturition. Anim Prod.; 54: 3616.

Perino, L.J. and Rupp, G.P. (1994): Immunization of the beef cow and its influence on fetal and neonatal calf health. Vet. Clin.North Am. 10: 15-33.

Pickard, R.M.; Beard, A.P.; Seal, C.J. and Edwards, S.A. (2005): Supplementation of ewe diets with algal biomass rich in docosahexaenoic acid for different time periods before lambing affects measures of lamb viability. Proceedings of the British Society of Animal Science Annual Meeting, p. 89.

Rashid, M.M.; Fisher, R.; Karrow, N.; Alzahal, O. and McBride, B.W. (2010): Fatty acid profile of colostrum and milk of ewes supplemented with fish meal and the subsequent plasma fatty acid status of their lambs. J Anim Sci. Jun; 88(6):2092-102.

Rattray, P.V.; Garrett, W.N.; East, N.E. and Hinman, $N$. (1974): Growth, development and composition of ovine conceptus and mammary-gland during pregnancy. J. Anim. Sci., 38: 613-626

$S A S$, (2001): Statistical analysis system. User's Guide Statistics. SAS Institute, Cary, North Carolina.

Segerson, E.C.; Gunsett, F.C. and Getz, W.R. (1986): Selenium-vitamin E supplementation and production efficiency in ewes marginally deficient in selenium. Livest. Prod. Sci., 14: 149-159.

Sheppard, A.D.; Blom, L. and Grant, A.B. (1984): Levels of selenium in blood and tissues associated with some selenium deficiency diseases in New Zealand sheep. N.Z. Vet. J., 32, pp. 91-95

Slee, J. (1981): A review of genetic aspects of survival and resistance to cold in newborn lambs. Livestock Production Science 8, 419-429.

Slee, J. and Springbett, A. (1986): Early post- natal behavior in lambs of ten breeds. Appl. Anim. Behav. Sci., 15: 229-240.

Slee, J.; Alexander, G.; Bradley, L.R.; Jackson, N. and Stevens, D. (1991): Genetic aspects of cold resistance and related characters in newborn Merino lambs. Aust. J. Exp. Agric. 31: 175-182.

Sobiech, P. and Kuleta, Z. (2002): Usefulness of some biochemical indicators in detection of early stages of nutritional muscular dystrophy in lambs. Small Rumin. Res., 45: 209-215.

Suttle, N.F.; Linklater, K.A. and Jones, D.G. (1991): Disorders Related to Trace Element Deficiencies. In: Diseases of Sheep. 2nd edition. Ed.W. B. Martin and I. D. Aitken. pp. 
238-250. Blackwell Scientific Publications, Oxford.

Suttle, N.F. and Jones, D.G. (1989): Recent developments in trace element metabolism and function: Trace elements, disease resistance and immune responsiveness in ruminants. $\mathrm{J}$. Nutr. 119: 1055.

Sykes, A.R. (1982): The shelter requirements of the newborn lamb. Proc. NZ Soc Anim Prod, 42: 7-11.

Sykes, A.R.; Griffiths, R.G. and Slee, J. (1976): Influence of breed, birth weight and weather on the body temperature of newborn lambs. Anim Prod, 22: 395-402.

Symonds, M.E.; Bird, J.A.; Clarke, L.; Gate, J. J. and Lomax, M. A. (1995): Nutrition, temperature and homeostasis during perinatal development. Exp. Physiol. 80: 907-940.
Turner, R.J. and Finch, J.M. (1990): Immunological malfunctions associated with low selenium vitamin $\mathrm{E}$ diets in lambs. Journal of Comparative Pathology, 126, 2200-2204.

Wilkinson, P.C. (1981): Techniques in clinical immunology. $2^{\text {nd }}$ Ed., Black well scientific publications, London.

Williamson, J. K.; Riley, M.L.; Taylor, A.N. and Sanson, D.W. (1996): Performance of nursing lambs receiving vitamin $\mathrm{E}$ at birth or from dams that received vitamin E. Sheep Goat Res. J. 12: 69-73.

Williamson, J.K.; Taylor, A.N.; Riley, M.L. and Sanson, D.W. (1995): The effect of vitamin E on lamb vigor. Proc. West. Sec. Am. Soc. Anim. Sci., 46: 77-79.

Young, D.S. (2001): Effects of disease on clinical laboratory tests. 4th ed. AACC 2001, Mar 1; 1504(1): 82-106.

\section{إضافة زيت السمك وحقن السيلينيوم وفيتامين ه للنعاج المصرية والمهجنة بالفتلندية في آخر الحمل:

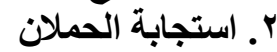
حمادة ضاحى حسين محبوب ، سامح جاد عبد الدق رمضان ، رجب عبل الله درويش ، محمد عاطف هلال ،

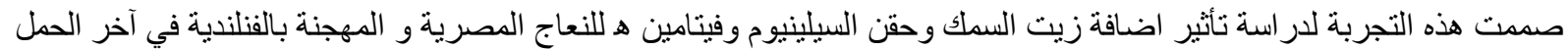

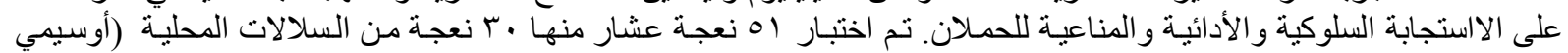

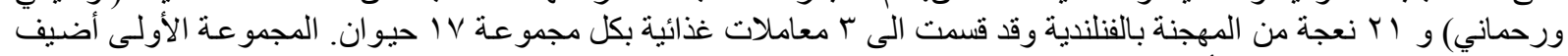

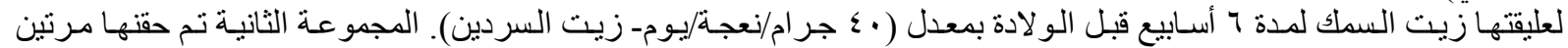

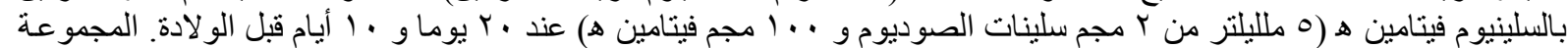

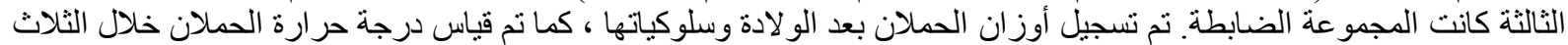

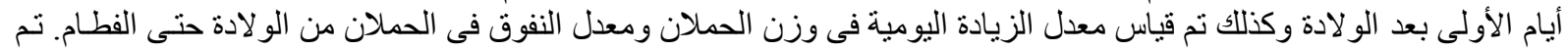

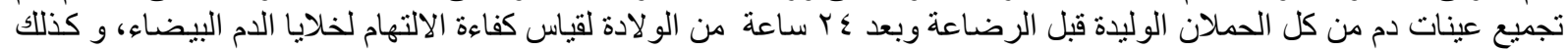

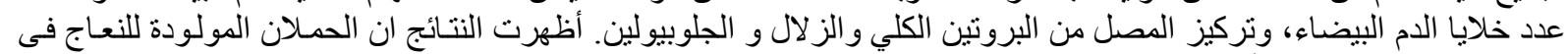

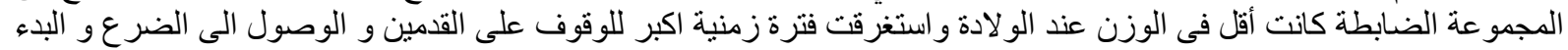

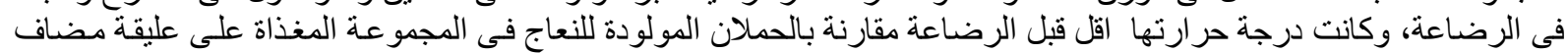

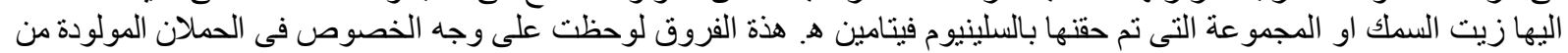

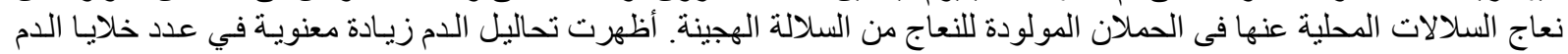

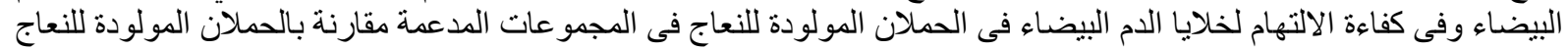

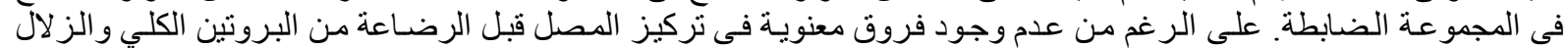

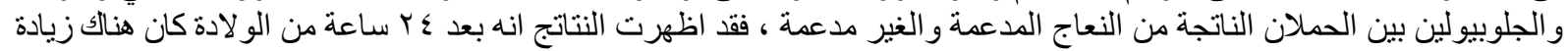

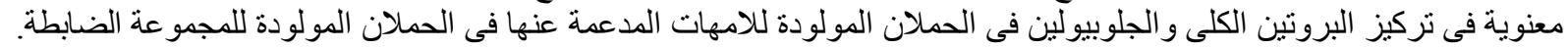

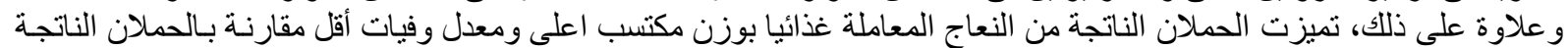

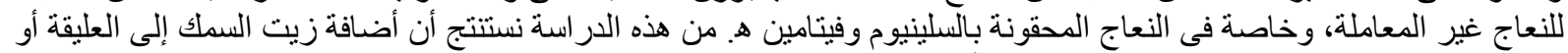

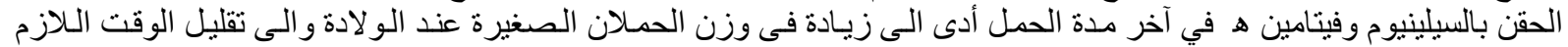

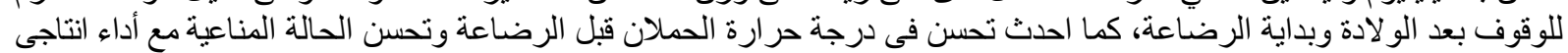

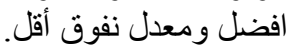

